\title{
POLITICAL ADJUDICATION OR STATUTORY INTERPRETATION: ROBINSON v SECRETARY OF STATE FOR NORTHERN IRELAND
}

\author{
Marie Lynch, Research Assistant, School of Law, Queen's \\ University Belfast*
}

Just before the House of Lords rose for its summer recess this year it delivered its judgment in the Robinson case. ${ }^{1}$ This eleventh hour delivery was widely anticipated not only by the parties but also by those working in the Northern Ireland Assembly where the case originated. ${ }^{2}$

Primarily Robinson concerns two major issues, statutory interpretation and statutory perception. Arising from the case are questions such as how the Northern Ireland Act 1998 is to be viewed; is it another statute produced by Westminster to be ranked alongside other primary legislation? Or should we see it as a unique enactment with the status equal or commensurate to that of a constitutional document? If the latter is the case, what will be the consequences for the future perception and interpretation of the Northern Ireland Act 1998? Will it discourage other potential challenges to the status of the Act? On a national level will the other devolution acts for Scotland or Wales be viewed in the same light?

Also stemming from the query as to the status of the Act is the wider issue of the judicial approach to statutory interpretation. Do judges interpret a statute like the Northern Ireland Act strictly legalistically, or is a more purposive, broader reading with reference to the preceding Belfast Agreement more appropriate? The use of Hansard further brings into question the propriety of reference to parliamentary debates as an aid to interpretation.

Robinson, where the judiciary were brought into the "campaign against the Agreement", also raises the issue of the appropriateness of involving the judicial body in these 'highly politicised' cases. As a reputedly apolitical institution, whose their independence from executive and partisan politics is highly valued, is there a danger that these values may be compromised when a court adjudicates on contentious political issues?

Outside the legal arena the effects of the Lords' judgment could have had immense practical ramifications. A finding in favour of the applicant would have meant the Assembly being dissolved and the call of immediate elections instead of the scheduled date in May 2003. ${ }^{3}$ In this paper the background to

* Currently working on a project entitled, The Role of Law and Litigation in Articulating Northern Ireland's Emerging Constitutional Framework, Funded by the Economic Social and Research Council (E.S.R.C. L219252114).

1 Robinson v Secretary of State for Northern Ireland and Others [2002] UKHL 32 (25 July 2002).

2 After the judgment was delivered Peter Robinson was quoted as saying that this phase of the campaign against the Belfast Agreement had come to an end. Irish News Friday 26 July 2002 p 11.

31 May 2003. 
the case will be outlined first and then the two main issues above will be discussed.

\section{General Background}

The case in question stems from a challenge taken by the deputy leader of the Democratic Unionist Party, Peter Robinson MP MLA, who claimed that the election of David Trimble and Mark Durkan as First Minister and Deputy First Minister (FM and DFM) on the 6 November 2001 was invalid.

David Trimble had resigned from the office of First Minister in protest at the conduct of Sinn Fein. Under section 16(7)(a) of the Northern Ireland Act 1998 (NIA), this action had the effect of leaving both offices (FM and DFM) vacant. As the sub-section provides:

"If either the First Minister or the deputy First Minister ceases to hold office at any time, whether by resignation or otherwise, the other - shall also cease to hold office at that time".

When the offices of FM and DFM become vacant, section 16(8) of the NIA stipulates that from that time:

"an election shall be held under this section to fill the vacancies within a period of six weeks beginning with that time."

If after this period has elapsed and the positions are not filled, section 32(3) directs the Secretary of State to propose a date for a poll for the election of the next Assembly.

On Friday 2 November 2001 the Assembly held an election to fill the offices of FM and DFM, as required by section 16(8) (this was two days before the six-week deadline that was set to run out on Sunday 4 November). However the candidates, Mr Trimble and Mr Durkan, failed to garner the support required to get elected. What followed was some circuitous and creative political manoeuvring whereby members of the Alliance Party and the Women's Coalition, ${ }^{4}$ re-designated themselves as either nationalists or unionist. This gave the two candidates the requisite support required to be elected on the second poll held Tuesday 6 November 2002. Later that day the Secretary of State proposed 1 May 2003 as the date for the poll for the election of the next Assembly. ${ }^{5}$

Peter Robinson's challenge centred on two issues. Firstly he argued that section 16(8) required the election of the FM and DFM to take place within six weeks. As the Assembly was a creature of statute it has only the powers conferred on it by statute, therefore the Assembly had no power to elect the

${ }^{4}$ Under Strand One, section 6 of the Belfast Agreement (Cm 3883), all members of the Assembly at their first meeting, must register a designation of identity nationalist, unionist or other. The criteria for electing the FM and DFM is also set out in Stand One, in s 15 and s 5(d)(i). These provisions only allow those designated as either unionist or nationalist to take part in the elections for FM and DFM. NIA section 16(3) implements these provisions.

5 On 11 December 2001, the Northern Ireland (Date of Next Assembly Poll) Order 2001 was passed, directing that the date for the next poll should be the date proposed, 1 May 2003. 
ministers after that period. Any election after the expiry of that date was invalid. Secondly he contended that if the offices were not filled within the six-week period, section 32(3) imposed a duty on the Secretary of State to propose a prompt and early date for the poll for the election of the next Assembly so that the political impasse could be resolved democratically by an appeal to the people. He considered that it was the duty of the courts to interpret and apply the NIA and not to take into account extraneous factors such as a disagreeable political outcome.

This argument was rejected in the High Court by Kerr J and in the Court of Appeal by Nicholson LJ and McCollum LJ, with the Lord Chief Justice, Sir Robert Carswell notably dissenting. Leave was granted to appeal to the House of Lords where a majority of the House (Lords Bingham, Hoffmann and Millett) also dismissed the case.

The majority in the House of Lords favoured the respondent Ministers and the Secretary of State's argument, which maintained that the provisions of the NIA should be interpreted so as to uphold the cross-community, devolved government where possible. This contention, based on the purpose of the Belfast Agreement, considered that if the Assembly failed to elect a FM and DFM within the six-week period, the Secretary of State was under no duty to fix an immediate date for a poll. Instead he was entitled to delay fixing a date and to wait for a reasonable period in order to establish whether the Assembly would succeed in electing a FM and DFM.

In accepting the respondents' argument the Lords rejected the purely declaratory approach to statutory interpretation advocated by the applicant, whereby they would pronounce the law as it is written in the NIA by providing a literal translation of the text and applying it to the facts at the centre of the dispute. The approach undertaken by Lords Bingham, Hoffmann and Millett was less traditional and favoured a more creative technique whereby the judge looks to the purpose of the statute. Here the aim is to determine the underlying principle or motivation behind the law, and use this rationale as an aid and guide to interpretation. This approach accommodates consideration of the background to the statute thereby enabling the judge to give a broader, more expansive interpretation of the law than what the alternative positivistic approach would provide.

That the latter approach was favoured is plainly evident in the majority's speeches. When examining the NIA, Lord Bingham addressed two questions; why the Act was enacted and in relation to this case, to what purpose? In answering these questions Lord Bingham, like Lord Hoffmann in his speech, ${ }^{6}$ drew upon the long title of the Act. From this it was evident that the Act was enacted primarily to implement the Belfast Agreement, to further its purpose to "end decades of bloodshed and centuries of antagonism", and to restore a devolved government to Northern Ireland in a manner which would be "significantly different" from previous attempts. ${ }^{8}$

One solution, considered by Lord Bingham to guarantee this difference was to ensure shared participation by unionists and nationalist communities in

6 [2002] UKHL 32, para 33.

7 Ibid, para 10.

8 Ibid, para 3. 
political institutions. Another was to be found in the establishment of the key offices of First Minister and Deputy First Minister (FM and DFM). In fact the vital roles of the FM and DFM in the functioning of the new democratic government in Northern Ireland is something that all the judges in Robinson have acknowledged. However those delivering the majority judgments focused in particular on the importance of the way these ministers were appointed. Certain stipulations contained in section 16 such as, the condition that they were to be filled by candidates elected jointly and on the basis that they obtain majority support from both designated nationalists and unionists members of the Assembly, were factors which Lord Bingham, ${ }^{9}$ Lord Hoffmann, ${ }^{10}$ and Lord Millett, ${ }^{11}$ believed were in keeping with the purpose and the cross community ethos of the Agreement. Lord Hoffmann acknowledged how important yet fragile these positions were would likely be:-

"It was obviously going to be a matter of delicate negotiation to secure, first, a joint ticket of two candidates willing to be yoked together and secondly, the three required majorities. But the positions occupied by the First and Deputy First Ministers made their election essential to enable devolved government to be carried on."12

Due to the potentially precarious nature of the Ministers' positions and the delicate nature of the devolved Assembly, ${ }^{13}$ it was Lord Bingham's opinion that if the "shared institution were to deliver the benefits which their progenitors intended, they had to have time to operate and take root."14

In consideration of this and the purposes that Parliament was seeking to promote, Lord Bingham felt that it was unlikely that Westminster would have wished to constrain local politicians and the Secretary of State within "a tight straightjacket."15 Accordingly, the duty contained in section 32(3) on the Secretary of State to propose a date for the poll for the next Assembly election should not be read so restrictively or rigidly as to require a prompt date as contended by the applicant. Rather a more generous and flexible interpretation of the NIA, which would allow scope for political discretion in order to deal with deadlocks and stalemates, would be more in keeping with the Act's purpose of creating a stable environment for cross-community government as set out in the Belfast Agreement.

In view of that, if an effective election of a FM and DFM did appear to be imminent then Lord Bingham would "expect" the Secretary of State to "pause" in order to take account of these developments. He should facilitate the political process and then propose a date in the future that would take account of the effective election. ${ }^{16}$ However Lord Bingham was in no doubt that the Secretary of State's discretion in such circumstances was limited. If

9 Ibid, para 5.

10 Ibid, para 27.

11 Ibid, para 89.

12 Ibid, para 27.

13 See in general Lord Bingham's speech, particularly paras 2 and 10.

14 [2002] UKHL 32, para 10.

15 Ibid, para 14

16 Ibid, para 15. 
there appeared to be no prospect of a pending election of the ministers or if the Assembly had resolved on an immediate dissolution, ${ }^{17}$ then the Secretary of State would be expected to propose a very early date for the poll. ${ }^{18}$

Facilitating this broad purposive approach to statutory interpretation, that permitted the Secretary of State such discretion in setting a date for the Assembly election, is the judicial perception of the NIA. In the course of their speeches both Lord Bingham and Lord Hoffmann referred to the NIA as a constitutional document. ${ }^{19}$ Lord Bingham was unambiguous when he stated that the NIA "is in effect a constitution." Such a categorisation is of great import, not only for the perceived status of the Act but also in that it permits greater latitude in interpretation..$^{20}$

These statements, confirming that the NIA should be viewed on par with a constitutional document, may enhance the significance of the NIA. However the judges in this instance considered that so to categorise the Act required more, it behoved the courts to interpret the constitutional provisions in issue "generously and purposively, bearing in mind the values which the constitutional provisions are intended to embody." $"$ And where constitutional arrangements retain scope for the exercise of political judgment, (as in the case of the discretion afforded to the Secretary of State under section 32(3)), "a more flexible response in light of unpredictable events is permitted." 22

Thus there is a consequence to viewing the Act in an elevated level; it entitles the interpreter to pay regard to the Act's background to ascertain its purpose and to use this information when interpreting and applying its provisions. In applying these principles of construction to the present case Lord Hoffmann considered that the NIA must be interpreted against the political backdrop of the situation in Northern Ireland and documents such as the Belfast Agreement and the principles contained therein. The utilisation of this background material, including the long title of the NIA, was permitted as aid to construction, for in Lord Hoffmann's opinion they "form part of the admissible background for the construction of the Act just as much as the Revolution, the Convention and the Federalist Papers are the background to construing the Constitution of the United States." 2.3

In this unequivocal statement concerning statutory interpretation and statutory perception, Lord Hoffmann firmly established the practice of using the Agreement and the political background of Northern Ireland as an aide to interpretation. However it is not just this emphatic affirmation of the

17 NIA s. 32(1)

18 [2002] UKHL 32, para 15.

19 See Lord Bingham at para 11; Lord Hoffmann at para 25 - the "1998 Act is a constitution for Northern Ireland"; Lord Millett at para 93.

20 See Thoburn v Sunderland City Council [2002] 3 WLR 247 at 280-281. In this case Lord Justice Laws categorised the European Communities Act 1972 as a constitutional statute and as such it could not be impliedly repealed. It is also of note that in this case Laws LJ considered the Scotland Act 1998 and the Government of Wales Act 1998 as constitutional statutes.

21 Lord Bingham at para 11.

22 Ibid, para 12.

23 Ibid, para 33. 
purposive approach to the judicial application of the NIA that makes this section of his speech worthy of note. Lord Hoffmann's correlation of the Belfast Agreement and its antecedents with the history and the employment of the historical legal text that precedes the United States Constitution say much for his actual perception of not only the NIA but the Agreement as well. By making this comparison he is affording to these documents a similar status to one of the oldest and most respected Constitutional documents in the modern Western world.

\section{An Alternative View}

Disagreeing with the majority's ruling that the provisions in the NIA should be construed in order to give effect to the objectives of the Belfast Agreement was Lord Hobhouse and the former Lord Chief Justice for Northern Ireland, Lord Hutton. ${ }^{24}$ Taking a literal approach to the interpretation of the NIA, both were of the opinion that the Northern Ireland Assembly was a body created by a Westminster statute and that it had no powers other than those given to it by statute..$^{25}$

In considering the extent to which the purpose of the NIA to implement the Agreement could affect the interpretation of sections 16 and 32, Lord Hutton did concede that it was necessary to keep in mind that the Belfast Agreement was drafted in the hope that the cross-community institutions of government would succeed. Nevertheless, although the Agreement made certain provisions allowing for review if difficulties arose across the range of institutions, he pointed out that the Agreement contained no express provision stating what would happen if the Assembly failed or did not continue. However Parliament had laid down the procedure to be followed if a scenario such as the failed election in the present case should happen. As such, while these provisions were in place, "the objective of the Belfast Agreement cannot operate to alter the meaning of their words." 26

This contention, that where Westminster has made legislative provision for certain developments, no extraneous factors may be taken into judicial consideration to alter their original intent is an argument that does bear merit. After all it is a basic constitutional tenet that Parliament is the supreme legislative entity in the United Kingdom. A political agreement, whilst clearly significant, does not have the legal status to alter the meaning or to overrule an Act of Parliament. Therefore, regardless of how influential agreements were in the creation of a piece of legislation, where Parliament has made provisions for a set of circumstances then these are the requirements which must be followed. Politically expedient considerations, even in the interests of stability, cannot be taken into account when such requirements exist.

Moreover Lord Hobhouse regarded the Secretary of State's refusal to call for a new election as required by section 32 as being contrary to the Agreement.

24 Appointed to the Law Lords in 1997.

25 Paraphrasing Lord Hutton at para 54. This statement was echoed almost word for word by Lord Hobhouse at para 66 - the Assembly is "entirely a creature of the Westminster statute."

26 Ibid, para 61. 
In Lord Hobhouse's view, the Secretary of State's decision over the election was political in character "as it is bound to favour one political party over the other", ${ }^{27}$ thereby failing to reflect the "inclusive aspirations of the Belfast Agreement."

This divergent opinion, in which Lord Hobhouse also regarded the Secretary of State's refusal to call an immediate election as undemocratic in that it denied the electorate the right to elect a new Assembly which was granted to them by the Act, is an argument of considerable force. The query as to democratic legitimacy and the allegation of political expediency in the majority's approach will remain one of the most controversial aspects of this case.

In Robinson and in the recent House of Lords' decision in the Northern Ireland Human Rights Commission (NIHRC) case, ${ }^{28}$ Lord Hobhouse drew upon the Belfast Agreement as an aid to interpretation. ${ }^{29}$ However in contrast to the majority's approach in Robinson, he considered that a strict construction of the Agreement was more appropriate. He appears to have viewed it as a contractual document, setting the limits of what the parties had agreed to, and not a loose set of principles to be applied quite flexibly.

\section{The Judicial Role and the Political Domain}

Those familiar with Lord Hobhouse's work in the House of Lords may not be surprised that he took such a literal approach to judicial interpretation in Robinson. ${ }^{30}$ In the NIHRC case, he alone delivered a dissenting speech. Finding against the appellants, Lord Hobhouse, like Lord Chief Justice Carswell in the High Court, was unable to read in the specific provisions of the NIA, an implied power as sought by the applicants. "Where the draftsman of the Act has wished to include incidental powers he has done so expressly." 31 Here the answer was unambiguous, unless the legislator had

27 Ibid, para 74 .

28 Re Northern Ireland Human Rights Commission [2002] UKHL 25 (20 June 2002). The appellants in this case, the Human Rights Commission (NIHRC), sought the power of intervention in order to make submissions on human rights law and practice to courts, tribunals and inquests. The majority had ruled that this power had not been explicitly laid out in s 69 of the NIA. Nevertheless after collective reading of the subsections contained within s 69 and a consideration of both the role of the NIHRC and the overall purpose of the NIA, the Lords ruled that the Commission did have a capacity to make submissions, if permitted by the court hearing the case.

${ }^{29}$ Ibid, para 63. It is of note, in contrast to his approach in Robinson, that in the NIHRC case Lord Hutton was willing to give a liberal approach to interpreting the NIA in determining the extent of the powers of the NIHRC. However this was because in this case he was of the view that the powers sought were "fairly incidental" to what was expressly authorised by s 69 . See paras $58-59$.

30 See for example, Fitzpatrick v Sterling Housing Association Ltd [2001] AC 27, at 67: "It is an improper usurpation of the legislative function, for a court to adopt social policies which have not been incorporated into the relevant legislation. . . it is a matter for parliament to consider, not for the courts to ask themselves: 'What would Parliament do now?"

${ }^{31}$ Re Northern Ireland Human Rights Commission (2002) UKHL 25, para 70. 
expressly provided for the power claimed, Lord Hobhouse was not going to view it as implicitly given.

From his speeches in the NIHRC and Robinson cases Lord Hobhouse would appear to be something of a black letter traditionalist. However there is another aspect to his favoured approach. In NIHRC he showed an appreciable reluctance to interfere with the provisions Parliament deemed necessary to give effect to the Belfast Agreement. He stressed that the Agreement was an "intensely political act", ${ }^{32}$ and considered the decision concerning how proactive and interventionist the NIHRC would be, to have been a political decision. In view of that, Lord Hobhouse considered any augmentation of the Commission's powers beyond those that were expressly granted matters for the executive and legislative branches, and not the judiciary who are not privy to the political rationale behind certain clauses. ${ }^{33}$

In Robinson and in NIHRC we have seen the courts operating in the areas of statutory interpretation and judicial review, which are traditional roles of a court in a constitutional democracy. However, devolution has added an extra dimension to these roles and invariably the courts are now being asked to become involved, whether they want to or not, in the difficult and contentious arena of Northern Ireland politics. Such involvement raises the problems which were acknowledged by Lord Chief Justice Carswell when delivering his Court of Appeal judgment in Robinson: "It is a difficult and invidious task for judges sitting in a court of law to adjudicate upon matters which have a highly charged political content, where the exercise of political judgment is at the centre of decision-making." ${ }^{34}$

The Lord Chief Justice clearly recognised the complexities which arise when the judiciary are required to move out from their traditional arena, as such involvement leaves them open to allegations that they take irrelevant and legalistically inappropriate factors such as the political consequences into consideration and leads to questions concerning their much prized neutrality. ${ }^{35}$

Addressing specifically the accusation that a finding in favour of the respondents in Robinson would be a politically expedient approach undertaken to provide the most convenient solution, Lord Hoffmann affirmed the principle that a judicial decision must "transcend any immediate result that is involved" and claimed that his construction of the Act satisfied these requirements. ${ }^{36}$ As indicated earlier, ${ }^{37}$ Lord Hoffmann was of the view

32 Ibid. para 66.

33 Ibid, para 68.

34 [2002] NI 206 at 219. See also his decision in the Re Williamson's Application [2000] NI 294.

35 After the ruling on his case was delivered, Peter Robinson was quoted as saying that the majority of the Law Lords preferred a "dangerously elastic and politically expedient approach." Irish News, Friday 26 July 2002.

36 [2002] UKHL 32, para 33. However both Lord Hoffmann and Lord Bingham in their reasoning did consider the effects of having an immediate Assembly election, a consequence of the literal interpretation of s 32(3). Both were of the opinion that such a development would be undesirable. By an analogy to the costly effects of "premature elections" called by Prime Ministers in the UK, Lord Hoffmann considered that this was an option that was not to be taken lightly (para 29). Lord 
that he was entitled to take into consideration the background facts and documents in the case. The perception of the NIA as a constitutional document permits judicial consideration of certain factors that otherwise would be considered inappropriate.

Considering the controversy surrounding this issue, the question remains whether or not Lord Hobhouse's approach is more preferable? Is his disinclination and unwillingness to lapse into issues that arise in the political domain more appropriate?

Providing an answer to this depends much upon the essential genre of a statute like the NIA. Is it to be viewed like the Law of Property Act 1925 or the Sale of Goods Act 1979 and given an essentially literal construction? With enactments like these natural persons and businesses sometimes invest significant sums on legal advice to ensure that business transactions are legally safe. Arguably they have a legitimate expectation that their advisers can assume a technical literal construction of the statute. By contrast a constitutional enactment like the NIA is designed to facilitate the political process. Arguably the approach of the majority allowed the political process to continue. It enabled a maximisation of political decisions to be taken by elected representatives and minimised the number of decisions taken by courts. Paradoxically, this approach may have contributed more to keeping courts out of the political arena.

Whether the judiciary in the future will be required to sit in judgment on potentially contentious issues will of course depend on whether applicants see the courts as a favourable forum in which to address their grievances. How the courts will react if and when they are required to sit in judgment on such cases will remain a source of much interest. What is clear however is the enhanced significance of the judicial role since Devolution.

\section{Reliance on Hansard as a Guide to Statutory Interpretation}

One striking feature of Robinson (perhaps unusual for a split judgment) was that there was one issue upon which all the Lords agreed. As part of counsel's argument for the appellant he had asked the court to consider statements made by Lord Dubs in the House of Lords during the passage of the Northern Ireland Bill. ${ }^{38}$ Lord Cope of Berkeley had asked whether there was any sanction in place if a failure to elect the ministers occurred within the six-week period. Lord Dubs had replied: "If the Assembly fails to make

Bingham considered that "elections held with undue frequency are not necessarily productive", and though they "may produce solutions" they can also "deepen divisions" (para 11).

${ }^{37}$ See $\mathrm{n} 23$ and text.

38 In Pepper v Hart [1993] AC 593, the House of Lords relaxed the self-imposed rule which precluded reference to statements made in Parliament as an external aid to construction of statutes. Such reference is now permissible only where: (a) legislation is ambiguous or obscure, or a literal construction would lead to an absurdity; (b) the material relied on consisted of one or more statements by a minister or other promoter of the Bill, together if necessary, with such other parliamentary material as might be necessary to understand such statements and their effect; and (c) the effect of such statements was clear. 
such an election within six weeks, it will be dissolved and the Secretary of State then sets the date for an extraordinary election." $" 39$

These remarks were relied upon by the appellant to show that Parliament intended that the expiry of the time limit should trigger an immediate election. ${ }^{40}$ Lord Bingham acknowledged that this statement did appear to give the appellant's argument some support. ${ }^{41}$ However he advised that it must be read in context. He pointed out that Lord Dubs was not considering what the position would be if at the end of the six-week period there had been no effective election but such an election was expected within a matter of days, because this was not the question that had been asked. Lord Hoffmann took a similar position. He was of the opinion that Lord Dubs had not given any thought to the question of whether the Assembly would retain power to elect after the expiry of the period and the answer that he did provide was a "perfectly adequate" explanation of the effect of the clause. ${ }^{42}$

Although Carswell LCJ had "attached some considerable weight"43 to the statement made by Lord Dubs, all those delivering the judgment in the House of Lords disagreed with his reliance on parliamentary debates in this case. As Lord Bingham pointed out: "It is not surprising that a minister, called upon at very short notice to answer a number of unexpected points, failed to speak with the precision expected of a parliamentary draftsman." ${ }^{44}$ The Law Lords were of the opinion that the task of interpreting legislation was not assisted by the "too ready" reference to what had been said during debates in the House of Lords. ${ }^{45}$

They further took the opportunity to criticise, not just in this case but in general, the utility of referring to debates in parliament, emphasising that the occasions will be very rare when statements made by members of Parliament will be of use in statutory construction. Lord Hoffmann even went as far as to say that Lord Mackay, who dissented in Pepper v Hart and warned of the disadvantages of the use of references to Hansard, may have turned out to be the "better prophet". ${ }^{46}$ Lord Mackay's objection centred on his belief that in almost all cases involving statutory interpretation, the parties' legal advisors would have to study Hansard to see whether or not any assistance could be derived from it. The expense of searching for useful material and the consequent increase in court time were other objections. On the whole Lord Mackay thought that access to Hansard would increase the cost of litigation without making an appreciable contribution to the quality of decisionmaking.

Robinson illustrates the force of Lord Mackay's objections. Little regard appears to have been given to the strict limits laid down in Pepper v Hart on the use of this material. The statement relied on was made during a lengthy

3919 October 1998. HL Deb col 1229.

40 This argument was rejected by Kerr $\mathrm{J}$ in the High Court and by Nicholson LJ in the Court of Appeal.

41 [2002] UKHL 32, para 17.

42 Ibid, para 38.

43 Ibid, para 17 (Lord Bingham).

44 Ibid.

45 Lord Hobhouse, para 65.

46 Para 39. 
and complex debate, ${ }^{47}$ where understandably little time was permitted for proper consideration of the question and its context. Perhaps the greatest objection to over-reliance on ministerial statements is that they are just statements, and cannot be said necessarily to reflect the intention of Parliament as a whole.

Despite various attempts by the House of Lords to curtail use of Hansard, ${ }^{48}$ reference to it is still fairly frequent. ${ }^{49}$ Robinson may now be cited as a cautionary example of liberal reliance on it. The unequivocal rejection of its use in that case is certainly an endorsement of the minimalist approach to Pepper v Hart and a tacit approval of Lord Mackay's dissent.

\section{CONCLUSION}

Following the extensive devolution programme a substantial body of legislation was introduced to accommodate the fundamental constitutional developments. The interpretation and application of legislation such as the NIA and the Scotland Act was left to the courts to determine. How these legislative enactments should be construed was a matter of academic debate. Would they be perceived in a manner similar to other primary legislation or would they be treated differently because of their constitutional importance? One of the most important aspects of the Robinson judgment was that it provided an authoritative ruling on the significance of an Act of Parliament such as the NIA. The judicial interpreter in NIA related cases is now entitled to have regard to the Act's background in the Belfast Agreement to consider its purpose and to apply this knowledge when interpreting its provisions. It would now seem that the approach adopted by Kerr $\mathbf{J}$ in the recently decided case of Re Parsons is the one that is favoured by the House of Lords. ${ }^{50}$ The one other major issue dealt with in Robinson was the use of Hansard in the interpretation of legislation. It would seem that another cautionary note has been sounded in this debate.

47 It should also be pointed out that Parliamentary debates often take place late at night in nearly empty chambers.

48 See Exp Spath Holme Ltd [2001] 2 AC 349; R v A (No 2) [2002] 1 AC 45.

49 [2002] UKHL 32, at para 40 (Lord Hoffmann).

50 Unreported (QBD). Here Kerr J, in interpreting the Police (Northern Ireland) Act 2000, cited the Agreement as an endorsement of the new recruitment policy which requires the new intake to comprise of 50\% Catholic and 50\% Protestant recruits. 